\title{
MEASURING THE COMPLEXITY OF A PHYSIOLOGICAL TIME SERIES: A REVIEW
}

Kazimieras Pukẻnas, Jonas Poderys, Remigijus Gulbinas

\author{
Lithuanian Academy of Physical Education, Kaunas, Lithuania
}

\begin{abstract}
Research background and hypothesis. Complex Systems Theory indeed is a solid basis for a scientific approach in the analysis of living, learning, and evolving systems. A number of different entropy estimators have been applied to physiological time series attempting to quantify its complexity.

Research aim. The aim of the paper is to review most popular complexity estimators (entropies) applied in biological, medical, sport and exercise sciences and their performances.

Research results. Various measures of complexity were developed by scientists to compare time series and distinguish regular (e. g. periodic), chaotic, and random behavior. In this paper a brief review of most popular complexity estimators - Sample Entropy, Control Entropy, Spectral Entropy, Wavelet Entropy, Singular-Value Decomposition Entropy, Permutation Entropy, Base-Scale Entropy, Entropy based on Lempel-Ziv algorithm - and their performances is presented. In biological applications they are used to distinguish peculiarities in behavior of biological systems or may serve as non-invasive, objective means of determining physiological changes under steady or non-steady state conditions.

Discussion and conclusions. The choice of a particular entropy estimator is determined by the goal type, the capability of estimators in characterizing the constraints on a physiological time series, its robustness to noise considering the above-mentioned advantages and disadvantages of particular algorithms. It is difficult to apply analytical solutions in the analysis of behavior of living, learning, and evolving systems and new approaches and solutions remain on the agenda.
\end{abstract}

Keywords: physiological time series, complexity, entropy.

\section{INTRODUCTION}

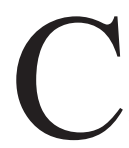
omplex Systems Theory indeed is a solid basis for a scientific approach in the analysis of living, learning, and evolving systems. A great number of details in the sequence of movements, a variety of situations which the player is required to face, a wide range of techniques and skills which the handling of those situations encoupan_consist the complexity which is required to understand in sport science. A hallmark of physiologic systems is their extraordinary complexity. This complexity arises from the interaction of a myriad of structural units and regulatory feedback loops that operate over a wide range of temporal and spatial scales, enabling the organism to adapt to the stresses of everyday life. The nonstationarity and nonlinearity of signals generated by living organisms defy traditional mechanistic approaches based on homeostasis and conventional biostatistical methodologies. Recognition that physiologic time series contain "hidden information" has fueled growing interest in applying concepts and techniques from the 
complexity theory, including fractal analysis and nonlinear dynamics, to a wide range of biomedical problems from molecular to whole body levels (Mayer, 2001; Goldberger et al., 2002). The use of non-linear methods for estimating variability in a given class of phenomena is very important to access the underlying nature of these processes. On the one hand, the variability in a time-series might entail relevant information on the underlying dynamics of the phenomenon, and, on the other hand, changes in the variability might inform us about deviations experienced by a system (Goldberger et al., 2002; Seely, Macklem, 2004). Once introduced, the family of statistics has been widely applied to a variety of physiological and clinical datasets such as genetic sequences, hormone pulsatility, respiratory patterns, heart rate variability, electrocardiography (ECG), electroencephalography (EEG), electromyography (EMG), datasets of gait analysis and postural control and other important physiological experimental time series and has shown its superiority to most complexity measures (Chena et al., 2009). Various measures of complexity were developed to compare time series and distinguish regular (e. g. periodic), chaotic, and random behavior. In this paper a brief review of most popular complexity estimators (entropies) applied in biological, medical, sport and exercise sciences and their performances are presented.

\section{TECHNIQUES REVIEW}

The main types of complexity parameters are:

- Information theory estimates of complexity (entropies);

- Fractal dimensions;

- Chaos-based estimates of complexity (Lyapunov exponents, etc.).

They are all defined for typical orbits of presumably ergodic dynamical systems, and there are profound relations between these quantities (Bandt, Pompe, 2002). At the heart of such analysis, is the concept of quantifying the information evolution of transitions associated with probabilities assigned to each state, with a goal of providing single value (an entropy) to describe this information content (Bollt, Skufca, 2009). With an appropriate finite partition of labeled states, $i=1,2, \ldots, n$, and a probability measure $p_{i}$ on that partition, the well known Shannon entropy of a random variable is defined by:

$$
S E=-\sum p_{i} \cdot \ln p_{i}
$$

The discrete distribution (which may be conditional on another variable) of values has high entropy if it is uniform and corresponds to an unpredictable variable, and low if the distribution is sharply peaked and the variable can be predicted. Other entropies are Tsallis entropy, Escort-Tsallis entropy, Renyi entropy (Rosso et al., 2006; Rosso et al., 2010). In this paper only the definition of statistical complexity measure in terms of just "disorder" or "information" is considered, leaving out the approach when the amount of complexity $C$ is obtained by computing the product between the entropy $H$, and a sort of distance to the equipartition state in the system named as the disequilibrium $D$ (Rosso et al., 2010):

$$
C=H \cdot D=-K \sum_{i=1}^{R} p_{i} \cdot \ln p_{i} \cdot \sum_{i=1}^{R}\left(p_{i}-\frac{1}{R}\right)^{2},
$$

where $H$ and $D$ are, respectively, the entropy and the disequilibrium, $p_{i}$ represents the probability associated to the state $i ; R$ is the number of states, and $K$ is a positive normalization constant.

The most popular entropy measures for complexity estimation of the physiological time series are:

- Approximate entropy - ApEn (Sample Entropy - SampEn);

- Control Entropy - CE;

- Spectral Entropy - SE;

- Wavelet Entropy - WE;

- Singular-Value Decomposition Entropy SVDEn;

- Permutation Entropy - PE;

- Base-Scale Entropy;

- Lempel-Ziv algorithm.

Sample Entropy (SampEn). Sample Entropy provides a characterization of time series complexity in terms of their regularity. SampEn $(m, r, N)$ is precisely the negative natural logarithm of the conditional probability that a dataset of length $N$, having repeated itself within a tolerance $r$ for $m$ points, will also repeat itself for $m+1$ points, without allowing self-matches (Richmann, Moorman, 2000): 


$$
\operatorname{SampEn}(m, r, N)=-\ln \left[A^{m}(r) / B^{m}(r)\right],
$$

where

$$
\begin{aligned}
& B^{m}(r)=(N-m)^{-1} \sum_{i=1}^{N-m} B_{i}^{m}(r), \\
& A^{m}(r)=(N-m)^{-1} \sum_{i=1}^{N-m} A_{i}^{m}(r),
\end{aligned}
$$

$B^{m}(r)$ is the number of vectors $\boldsymbol{x}_{m}(j)$ within $r$ of $\boldsymbol{x}_{m}(i)$, where $j$ ranges from 1 to $N-m(j \neq i), A^{m}(r)$ is the number of vectors $\boldsymbol{x}_{m+1}(j)$ within $r$ of $\boldsymbol{x}_{m+1}(i)$, where $j$ ranges from 1 to $N-m(j \neq i)$. Sample Entropy is a useful tool for investigating the dynamics of heart rate and other time series, when the assumption of the stationarity of time series is fulfilled. One of the main advantages of the SampEn analysis is that it can be applied to both deterministic and stochastic systems (see (Ramdani et al., 2009) for more details).

Control Entropy (CE). The Control Entropy is closely related to the technique of SampEn, but is defined in terms of the first difference of the signal, via correlation sums (Bollt, Skufca, 2009; McGregor et al., 2009). The effect of short time correlation is removed by using a Theiler window. Given a scalar data set $\left\{z_{i}\right\}_{i=1}^{N}$ from an ergodic process, the Control Entropy is defined as

$$
C E\left(\left\{z_{i}\right\} ; m, r, T\right)=\ln \frac{C_{2}\left(\left\{z_{i}\right\}, m, r, T\right)}{C_{2}\left(\left\{z_{i}\right\}, m+1, r, T\right)},
$$

where $C_{2}$ is the correlation sum

$$
\begin{aligned}
& C_{2}\left(\left\{z_{i}\right\} ; m, r, T\right)= \\
& =\frac{1}{N_{\text {pairs }}} \sum_{i=m}^{N} \sum_{j>i+T} \Theta\left(r-\left\|\boldsymbol{v}_{i}-\boldsymbol{v}_{j}\right\|\right), \\
& \boldsymbol{v}_{i}=\left(z_{i}, z_{i-1, \cdots, z_{i-m+1}}\right),
\end{aligned}
$$

where $\Theta$ is the Heaviside function, $m$ is the embedding dimension, $r$ is a parameter defining a neighborhood, and $N_{\text {pairs }}$ is the total number of pairs of delay vectors $\boldsymbol{v}$, integer parameter $\mathrm{T} \geq 1$ is a Theiler window used to mitigate effects of time correlation in the data. The control entropy should be calculated in a moving window along the time series and is a tool that is not subject to conditions of stationarity and is generally applicable to any measurement signal, but, in particular, it is well suited to monitoring streaming continuous signal that is recorded at high frequencies (Bollt, Skufca, 2009). This is in contrast to other commonly used regularity statistics that are typically applied to discretized samples, e.g., stride rate, $R$ - $R$ interval of heart rate, etc. This characteristic could allow researchers to exploit the more robust information properties of streamed waveforms which may provide a novel insight into the regularity of physiological parameters (McGregor et al., 2009). It is found (McGregor et al., 2009) that symbolization of time series adds a great deal of stability but still has sufficient robustness and rapid convergence relative to continuous $r$-neighborhood statistic.

Spectral Entropy (SE). The SE (Inouye et al., 1991) is the Shannon entropy formula suitably normalized and applied to the power spectral density of the signal:

$S E=-\sum p_{k} \cdot \ln p_{k} / \ln N$,

where $p_{k}$ are the normalized spectral amplitudes of frequency bin $k, N$-number of frequencies and $\sum p_{k}=1$. The SE is a measure of how concentrated or widespread the Fourier power spectrum of a signal is - the SE can take values from zero (if the spectrum contains purely a single oscillatory peak) to one (if the spectrum is that of uncorrelated white noise - i. e. $p_{k}=1 / N$ ). SE quite often is the easiest compute if the data sets are large. However, the applicability of this method to short lasting and nonstationary data segments has restrictions - the Fourier transform (FT) requires stationarity of the signal. The disadvantages of the spectral entropy defined from the FT can be partially resolved by using a short time Fourier transform (Rosso et al., 2001). Another drawback of SE is insufficient sensitivity. To overcome these limitations a time evolving entropy can be defined from a timefrequency representation of the signal as provided by the wavelet transform.

Wavelet Entropy (WE). Wavelet analysis is a method which relies on the introduction of an appropriate basis and a characterization of the signal by the distribution of amplitude in his basis. Wavelet analysis is a suitable tool for detecting and characterizing specific phenomena in time and frequency planes (see (Rosso et al., 2001; Rosso et al., 2006) for more details). The WE is defined as (Rosso et al., 2001; Rosso et al., 2006)

$W E=-\sum p_{j} \cdot \ln p_{j} / \ln N$,

$p_{j}=E_{j} / E_{t o t}$, 


$$
\begin{aligned}
& E_{j}=\sum_{k}\left|C_{j}(k)\right|^{2}, \\
& E_{\text {tot }}=\sum_{j} \sum_{k}\left|C_{j}(k)\right|^{2},
\end{aligned}
$$

where $C_{j}(k)$ are the discrete wavelet transform coefficients at octave $j$ and time $k$. The WE carries information about the degree of order/disorder associated with a multi-frequency signal response and on the other part can provide additional information about the underlying dynamical process associated with the signal. In contrast to SE, WE are capable of detecting changes in a nonstationary signal due to the localization characteristics of the wavelet transform.

Singular-Value Decomposition Entropy (SVDEn). Given a time series $\left\{x_{i}\right\}_{i=1}^{L}$ the phase points can be reconstructed by time delay embedding (Kantz, Schreiber, 2003):

$$
\left\{\overrightarrow{\boldsymbol{x}}_{i}\right\}_{i=1}^{L-(d-1) \tau}
$$

where $\quad \overrightarrow{\boldsymbol{x}}_{i}=\left[x_{i}, x_{i+\tau}, x_{i+2 \tau}, \cdots, x_{i+(d-1) \tau}\right]^{T}$,

$L$ - length of time series; $\tau$ - time delay; $d$ - the embedding dimension; $(\cdot)^{T}$ denotes the transpose of a real matrix. Taking the standard singular value decomposition on the covariance matrix of reconstructed phase space matrix:

$\mathrm{R}=\mathrm{U} \Lambda \mathrm{V}^{\mathrm{T}}$,

the SVDEn is computed via the equation (Sabatini, 2000):

$$
\text { SVDEn }=-\sum \lambda_{k} \cdot \ln \lambda_{k} / \ln K,
$$

where $\lambda_{k}-$ normalized $k$-th eigenvalue; $K$ - number of eigenvalues.

In essence, similar to the Spectral Entropy, the SVDEn measure estimates the deviation of the singular values away from a uniform distribution more complex systems are characterized by a spread of energy away from the first singular values.

Permutation Entropy (PE). This measure quantifies the diversity of orderings of symbols derived from a scalar time series $\left\{x_{i}\right\}_{i=1}^{L}$ by reordering the amplitude values (Bandt, Pompe, 2002; Staniek, Lehnertz, 2007). The permutation entropy of order $n \geq 2$ is defined as
$H(n)=-\sum p(\pi) \cdot \ln p(\pi) /(n-1)$,

where the sum runs over all $n$ ! permutations $\pi$ of order $n ; p(\pi)$ - the relative frequency of permutations. Permutation entropy is the Shannon entropy of $n$ distinct symbols:

$0 \leq H(n) \leq \ln n ! /(n-1)$,

where the lower bound is attained for an increasing or decreasing sequence of values, and the upper bound for a completely random system (independent and identically distributed - i. i. d. sequence) where all $n$ ! possible permutations appear with the same probability. Permutation entropy is an appropriate complexity measure for chaotic time series, in particular in the presence of dynamical and observational noise. Permutation entropies can be calculated for arbitrary real-world time series with a weak stationarity assumption (Bandt, Pompe, 2002). Since the method is extremely fast and robust, it seems preferable when there are huge data sets and no time for preprocessing and finetuning of parameters (Staniek, Lehnertz, 2007).

Base-Scale Entropy. First the time series are embedded in a $d$-dimensional space by Eq. For each $d$-dimensional vector, the base scale $Z_{B S}$ is calculated by defining the base scale as the root mean square of the differences between every two contiguous data points in a $d$-dimensional vector (Li, Ning, 2006)

$Z_{B S}(i)=\sqrt{\sum_{j=1}^{d-1}\left(x_{i+j}-x_{i+j-1}\right)^{2} /(d-1)}$.

Based on the base scale, the partition standard can be selected as a $\times Z_{B S}$ and each $d$-dimensional vector is transformed into a symbolic sequence on the basis of the four given levels alphabet (Li, Ning, 2006). The symbolic sequences $S_{i}(d$-words) at most have $4 d$ different forms $\pi$ since they are made up of four symbols, $0,1,2$, and 3 . The base-scale entropy of the $d$-dimensional vector is defined as

$H(d)=-\sum P(\pi) \cdot \log _{2} P(\pi)$,

where $P(\pi)$ - the relative frequency for each $\pi$. The base-scale entropy method essentially quantifies the uncertainty of the occurrence of $d$-words form. The advantages of base-scale entropy are simplicity and extremely fast calculation for very short data sets. This method enables to analyze very short, 
nonstationary, and noisy data series, so the basescale entropy can be directly applied to real-world time series (Li, Ning, 2006).

Lempel-Ziv (LZ) algorithm. LZ complexity analysis is based on a coarse-graining of the measurements, so before calculating the complexity measure, the signal must be transformed into a finite symbol sequence (commonly into a $0-1$ sequence) - the median, average and clusters conversion methods are used. LZ complexity is related to the number of distinct substrings and the rate of their recurrence along the given sequence, with larger values corresponding to more complexity in the data (Abasolo et al., 2006; Radhakrishnan et al., 2000). It is a nonparametric, simple-to-calculate measure of complexity in a one-dimensional signal that does not require long data segments to compute.

\section{DISCUSSION AND CONCLUDING REMARKS}

It is simple (and tempting) to borrow one of the developed appreoaches from another field that shares "key words" (Hristovski et al., 2010; Latash et al., 2010). This can provide tools that may help to find answers to questions after the questions have been formulated. The application of complex systems theory to sports is relatively new. Complex systems are well represented in their universal features by biological, evolutionary systems and that means that we can observe classes of behavior and transitions between those types of behavior that do not depend on the details of the system that is studied (Mayer, 2001). The methods applying to human data analysis are very important because many crucial variables are not directly measurable or even identifiable (Torrents, Balagué, 2006; Latash et al., 2010; Poderys et al., 2010). All the above-named and other algorithms of complexity measuring are used to compute the regularity of time series and classify the time series as being of one type or another on this basis. Entropybased regularity and complexity measures have been highly effective in analyzing a broad range of physiological signals (Karmakar et al., 2012). In many biological applications, they have been used to distinguish "healthy" from "unhealthy" biological signals or may serve as a non-invasive, objective means of determining physiological changes under steady or non-steady state conditions such as competition or acute clinical pathologies. As an extension of these applications, the problem of continuous health monitoring is considered, where the time series is not a fixed and complete set, but is "streaming." If we can associate a change in signal complexity with a change in the health of the system, then we might hope that entropy like measure might detect a developing problem (and possibly provide some warning before system failure) (Goldberger et al., 2002; Hristovski, Balagué, 2010). The choice of the particular entropy estimator is determined by the goal type, the capability of estimators in characterizing the constraints on a physiological time series, its robustness to noise considering the above-mentioned advantages and disadvantages of particular algorithms.

There is a fundamental problem with the scientific approach in that it requires abstraction and simplification in order to be formalized in a mathematical model. The process of simplification and abstraction has been extremely successful in describing the physical world but up to now it is not so clear if the same analytical approach could be always successfully applied to living objects (Mayer, 2001; Torrents, Balagué, 2006). For example, multiscale entropy has been widely used to quantify a system's complexity by taking into account the multiple time scales inherent in physiologic time series (Blasco-Lafarga et al., 2010; Hu, Liang, 2012). The multiscale analysis of physiologic time series such as the RR interval time series has revealed that the entropy differs according to the scale (Cysarz et al., 2011). It is difficult to apply analytical solutions in analysis of behavior of living, learning, and evolving systems and new approaches and solutions remain on the agenda. 


\section{REFERENCES}

Abasolo, D., Hornero, R., Gomez, C., Garcia, M., Lopez, M. (2006). Analysis of EEG background activity in Alzheimer's disease patients with LempelZiv complexity and central tendency measure. Medical Engineering \& Physics, 28, 315-322.

Bandt, Ch., Pompe, B. (2002). Permutation entropy: A natural complexity measure for time series. Physical Review Letters, 88, (17), 174102-1-174102-4.

Blasco-Lafarga, C., Martínez-Navarro, I., Sisamón, M. E. et al. (2010). Linear and nonlinear heart rate dynamics in elderly inpatients. Relations with comorbidity and depression. Medicina (Kaunas), 46 (6), 393-400.

Bollt, E. M., Skufca, J. D. (2009). Control entropy: A complexity measure for nonstationary signals. Mathematical Biosciences and Engineering, 6 (1), 1-25. Chena, W., Zhuang, J., Yu, W., Wang, Z. (2009). Measuring complexity using FuzzyEn, ApEn, and SampEn. Medical Engineering \& Physics, 31, 61-68.

Cysarz, D., Edelhauser, F., Van Leeuwen, P. (2011). Multiscale analysis of acceleration and deceleration of the instantaneous heart rate using symbolic dynamics. Conference Proceeding IEEE Engineering in Medicine and Biology Society: 1965-1968.

Goldberger, A. L., Peng, C.-K., Lipsitz, L. A. (2002). What is physiologic complexity and how does it change with aging and disease? Neurobiology of Aging, 23, 23-26.

Hristovski, R., Balagué, N. (2010). Fatigue-induced spontaneous termination point-nonequilibrium phase transitions and critical behavior in quasi-isometric exertion. Human Movement Science, 29 (4), 483-493.

Hristovski, R., Venskaitytė, E., Vainoras, A., Balagué, N., Vazquez, P. (2010). Constraints-controlled metastable dynamics of exercise-induced psychobiological adaptation. Medicina (Kaunas), 46 (7), 447-453.

Hu, M., Liang, H. (2012). Adaptive multiscale entropy analysis of multivariate neural data. IEEE Transaction on Biomedical Engineering, 59 (1), 12-15.

Inouye, T., Shinosaki, K., Sakamoto, H. et al. (1991). Quantification of EEG irregularity by use of the entropy of the power spectrum. Electroencephalography and Clinical Neurophysiology, 79, (3), 204-210.

Kantz, H., Schreiber, T. (2003). Nonlinear Time Series Analysis. Cambridge: Cambridge University Press.

Karmakar, C., Khandoker, A., Begg, R., Palaniswami, M. (2012). Understanding ageing effects using complexity analysis of foot-ground clearance during walking. Computer Methods in Biomechanics and Biomedical Engineering, 30 [Epub ahead of print].

Latash, M. L., Mindy, F., Levin, J., Scholz, P., Schöner, G. (2010). Motor control theories and their applications. Medicina (Kaunas), 46 (6), 382-392.
Li, J., Ning, X. (2006). Dynamical complexity detection in short-term physiological series using base-scale entropy. Physical Review E, 73, 052902-1-052902-4.

Mayer, G. J. (2001). Complex Systems as Fundamental Theory of Sports Coaching. Internet link: http://arxiv. org $/ \mathrm{html} / \mathrm{nlin} / 0111009$.

McGregor, S. J., Busa, M. A., Skufca, J., Yaggie, J. A., Bollt, E. M. (2009). Control entropy identifies differential changes in complexity of walking and running gait patterns with increasing speed in highly trained runners. Chaos, 19, (2), 026109-1-026109-13.

Poderys, J., Venskaitytè, E., Poderienè, K., Buliuolis, A., Vainoras, A. (2010). Functional state assessment on the dynamics of interparametric concatenations during exercise tests. Medicina (Kaunas), 46 (6), 429-434.

Radhakrishnan, N., Wilson, J. D., Loizou, P. C. (2000). An alternate partitioning technique to quantify the regularity of complex time series. International Journal of Bifurcation and Chaos, 10 (7), 1773-1779.

Ramdani, S., Bouchara, F., Lagarde, J. (2009). Influence of noise on the sample entropy algorithm. Chaos, 19 (1), 013123-1-013123-7.

Richmann, J. S., Moorman, J. R. (2000). Physiological time series analysis using approximate entropy and sample entropy. American Journal of Physiology Heart and Circulatory Physiology, 278, 2039-2049.

Rosso, O. A., Blanco, S., Yordanova, J. et al. (2001). Wavelet entropy: A new tool for analysis of short duration brain electrical signals. Journal of Neuroscience Methods, 105, 65-75.

Rosso, O. A., De Micco, L., Larrondo, H. A., Martin, M. T., Plastino, A. (2010). Generalized Statistical Complexity Measure. International Journal of Bifurcation and Chaos, 20 (3), 775-785.

Rosso, O. A., Martin, M. T., Figliola, A., Keller, K., Plastino, A. (2006). EEG analysis using wavelet-based information tools. Journal of Neuroscience Methods, 153, 163-182.

Sabatini, A. M. (2000). Analysis of postural sway using entropy measures of signal complexity. Medical \& Biological Engineering \& Computing, 38, 617-624.

Seely, A. J. E., Macklem, P. T. (2004). Complex systems and the technology of variability analysis. Critical Care, 8, 367-384.

Staniek, M., Lehnertz, K. (2007). Parameter Selection For Permutation Entropy Measurements. International Journal of Bifurcation And Chaos, 17 (10), 3729-3733.

Torrents, C., Balagué, N. (2006). Dynamic systems theory and sports training. Extrapolation, V, 60 (1), 72-83. 


\title{
FIZIOLOGINIŲ LAIKO EILUČIUU KOMPLEKSIŠKUMO IVERČIŲ APŽVALGA
}

\author{
Kazimieras Pukẻnas, Jonas Poderys, Remigijus Gulbinas \\ Lietuvos kūno kultūros akademija, Kaunas, Lietuva
}

\section{SANTRAUKA}

Tyrimo pagrindimas ir hipoteze. Kompleksiniu sistemu teorija teikia nauju galimybiu tyrëjams moksliniu požiūriu vertinti organizmą, biologinių ar kitų besivystančių sistemų ypatybes. Pastaraisiais metais fiziologinių laiko eilučių kompleksiškumo ìvertinimui pasiūlyta didelè metodų i̇vairovè. Entropijos vertinimo metodai vis plačiau taikomi fiziologinių laiko eilučių tyrinèjimų metu norint išreikšti kiekybini jų sudėtingumą.

Tikslas - pateikti tyrejjams populiariausių kompleksiškumo i̇verčių (entropijos), taikomų biologijos, medicinos, sporto mokslų srityje, apžvalgą.

Rezultatai. Apžvalgoje supažindinama su populiariausais kompleksiškumo vertinimo metodais (imties entropijos (angl. Sample Entropy), kontrolès entropijos (angl. Control Entropy), spektro entropijos (angl. Spectral Entropy), vilnelių entropijos (angl. Wavelet Entropy), dekompozicijos singuliarinėmis reikšmėmis entropijos (angl. Singular-Value Decomposition Entropy), perstatinių entropijos (angl. Permutation Entropy), pagrindinès skalès entropijos (angl. Base-Scale Entropy), entropijos pagal Lempel-Ziv algoritmą (angl. Entropy based on Lempel-Ziv algorithm)), apibūdinami pagrindiniai jų ypatumai ir taikymo sritys.

Aptarimas ir išvados. Ivvairūs entropijos vertinimai gali būti taikomi tyrinèjant sudètingų kompleksinių, adaptatyvių sistemų elgsenos ypatybes, tačiau pasirenkant vertinimo būdą svarbu atsižvelgti i pasirinkto algoritmo pranašumus ir trūkumus, vertinamo proceso (laiko eilučių) ypatybes. Analitiniai gyvų sistemų tyrinéjimai yra pakankamai sudètingas uždavinys, todèl naujų požiūrių ir sprendimų paieška tebelieka aktualiu nūdienos mokslų uždaviniu.

Raktažodžiai: fiziologinès laiko eilutès, kompleksiškumas, entropija. 